\title{
Power in International Politics
}

\author{
Michael Barnett and Raymond Duvall
}

\begin{abstract}
The concept of power is central to international relations. Yet disciplinary discussions tend to privilege only one, albeit important, form: an actor controlling another to do what that other would not otherwise do. By showing conceptual favoritism, the discipline not only overlooks the different forms of power in international politics, but also fails to develop sophisticated understandings of how global outcomes are produced and how actors are differentially enabled and constrained to determine their fates. We argue that scholars of international relations should employ multiple conceptions of power and develop a conceptual framework that encourages rigorous attention to power in its different forms. We first begin by producing a taxonomy of power. Power is the production, in and through social relations, of effects that shape the capacities of actors to determine their circumstances and fate. This general concept entails two crucial, analytical dimensions: the kinds of social relations through which power works (in relations of interaction or in social relations of constitution); and the specificity of social relations through which effects are produced (specific/direct or diffuse/indirect). These distinctions generate our taxonomy and four concepts of power: compulsory, institutional, structural, and productive. We then illustrate how attention to the multiple forms of power matters for the analysis of global governance and American empire. We conclude by urging scholars to beware of the idea that the multiple concepts are competing, and instead to see connections between them in order to generate more robust understandings of how power works in international politics.
\end{abstract}

The potentially system-defining attacks of September 11, the war on terrorism, and the U.S. invasion and occupation of Iraq have caused scholars and practitioners to refocus attention on a central concept in international politics: power. If the past is a good predictor of the future, however, debate is likely to be limited

This article was first presented at a conference, "Who Governs in Global Governance?" at the University of Wisconsin-Madison. We thank the participants at the conference, including Emanuel Adler, Alex Wendt, Neta Crawford, Kathryn Sikkink, Helen Kinsella, Martha Finnemore, Jutta Weldes, Jon Pevehouse, Andrew Hurrell, John Ruggie, and especially Duncan Snidal, Robert Keohane, and Charles Kupchan. Other versions were presented at the University of Minnesota and the International Studies Association meetings in Budapest, Hungary in June, 2003. We also want to thank Kurt Burch, Thomas Diez, Tom Donahue, William Duvall, Ayten Gundogdu, Stefano Guzzini, Colin Kahl, Amit Ron, Latha Varadarajan, Michael Williams, Anne-Marie Slaughter, the editors of the journal, and two anonymous reviewers. We also acknowledge the bibliographic assistance of Emilie Hafner-Burton and Jonathan Havercroft.

International Organization 59, Winter 2005, pp. 39-75

(C) 2005 by The IO Foundation.

DOI: $10.1017 /$ S0020818305050010 
conceptually, informed primarily by a realist conception of power-the ability of states to use material resources to get others to do what they otherwise would not. Indeed, this is already happening. Much of the conversation triggered by the U.S. invasion of Iraq, for instance, has focused on unipolarity, the ability of the United States to use its military and economic resources to overcome resistance by states and nonstate actors, and whether other states will balance against or bandwagon with U.S. power. Certainly, any consideration of power in international politics must include such questions. But, Mae West's views notwithstanding, too much of a good thing is not always wonderful. Instead, it can produce theoretical tunnel vision that causes scholars to overlook others forms and effects of power. In this essay we argue that scholars of international relations must work with multiple conceptions of power, suggest how they can accomplish this task, and demonstrate how a consideration of power's polymorphous character will enhance and deepen theoretic understanding of international politics.

Ever since Carr delivered his devastating rhetorical blow against the "utopians" and claimed power for "realism," the discipline of international relations has tended to treat power as the exclusive province of realism. ${ }^{1}$ Accordingly, a concern with power in international politics is frequently interpreted as a disciplinary attachment to realism. Associated with this tendency, there is a widely accepted conceptualization that is viewed as the only way to understand power: how one state uses its material resources to compel another state to do something it does not want to do. Most introductory texts to international relations cleave to this formulation. Attempts by scholars to operationalize power follow from this definition. ${ }^{2}$ The substantial literature on the "paradoxes of power" revolves around the disconnect between capabilities and outcomes. ${ }^{3}$

The disciplinary tendency to associate power with realism and to work primarily with the realist conceptualization partly owes to the fact that rivals to realism typically distance themselves from "power" considerations. ${ }^{4}$ This feature has been especially visible in recent years, as neoliberal institutionalists, liberals, and constructivists have attempted to demonstrate their theoretical salience by demonstrating how "power" variables are not causally consequential in their explanation of empirical outcomes. Neoliberals have argued how states with convergent interests create international institutions and arrangements that effectively tame (state) power, highlighting processes of social choice and leaving the impression that institutions are the antidote to power. ${ }^{5}$ Scholars of liberal international relations theory typically stress that many important international outcomes cannot be adequately explained with reference to power, but instead are better understood by the salu-

1. Carr 1964.

2. See Mansfield 1993; Stoll and Ward 1989; Ray and Singer 1973; and Mearsheimer 2001.

3. See Baldwin 1989; and Maoz 1989.

4. We recognize this narrative of the discipline necessarily overlooks other contributions that never pivoted around realism. Later in the article we introduce some of these alternative perspectives.

5. See Keohane 1984; and Keohane and Martin 1995. 
tary presence of democracy, particular configurations of domestic interests, liberal values, economic interdependence, or international institutions. ${ }^{6}$ Mainstream constructivists, too, have pitted themselves against explanations in terms of power as they have attempted to demonstrate the causal significance of normative structures and processes of learning and persuasion. ${ }^{7}$

Because these rivals to realism have juxtaposed their arguments to realism's emphasis on power, they have neglected to develop how power is conceptualized and operates within their theories. It could have been otherwise. These theoretical approaches draw from distinct social theoretic traditions that offer critical insights into the forms and effects of power. Although neoliberal institutionalists have tended to highlight how international institutions produce cooperation, they could just as easily have emphasized how institutions shape the bargaining advantage of actors, freeze asymmetries, and establish parameters for change that benefit some at the expense of others. Although liberals have tended to limit their claims to the liberalism of "progress," they could have developed the liberalism of "fear" that is more centrally concerned with power. ${ }^{8}$ Although constructivists have emphasized how underlying normative structures constitute actors' identities and interests, they have rarely treated these normative structures themselves as defined and infused by power, or emphasized how constitutive effects also are expressions of power. A consequence of this failure to develop alternative conceptualizations of power has been to reinforce the discipline's gravitation toward the default conception as defined by realism. Yet, as famously noted by Gallie, and as repeated by social theorists ever since, power is an essentially contested concept. ${ }^{9}$ Its status owes not only to the desire by scholars to agree to disagree, but also to their awareness that power works in various forms and has various expressions that cannot be captured by a single formulation.

The failure to develop alternative conceptualizations of power limits the ability of international relations scholars to understand how global outcomes are produced and how actors are differentially enabled and constrained to determine their fates. One certainly needs to know about the ability of actors to use resources to control the behavior of others. The United States is able to use its military power to compel others to change their foreign policies, and in the contemporary period transnational activists have been able to shame multinational corporations and abusive governments to alter their economic and human rights policies, respectively. Any discussion of power in international politics, then, must include a consideration of how, why, and when some actors have "power over" others. Yet one also needs to consider the enduring structures and processes of global life that enable and constrain the ability of actors to shape their fates and their futures. The exten-

6. See Moravcsik 1997; and Slaughter 1995.

7. See Katzenstein 1996; Risse 2001; Checkel 2001; and Finnemore 2003.

8. Keohane 2002.

9. Gallie 1956. 
sion of sovereignty from the West to the developing world gave decolonized states the authority to voice their interests and represent themselves, and the emergence of a human rights discourse helped to make possible the very category of human rights activists who give voice to human rights norms. Analysis of power in international relations, then, must include a consideration of how social structures and processes generate differential social capacities for actors to define and pursue their interests and ideals. ${ }^{10}$

The starting point for opening the conceptual aperture is to identify the critical dimensions that generate different conceptualizations of power. In general terms, power is the production, in and through social relations, of effects that shape the capacities of actors to determine their circumstances and fate. ${ }^{11}$ The general concept of power that we employ is restricted to the production of particular kinds of effects, namely those on the capacities of actors to determine the conditions of their existence. There is an alternative tradition that sees power as the production of any and all effects and thus as nearly synonymous with causality. ${ }^{12}$ What does this alternative tradition keep in that we leave out? It includes social relations of joint action through mutual agreement and interactions in which one actor is able to convince another actor to alter voluntarily and freely its beliefs, interests, or action. Persuasion, then, is social causation but falls outside of our concept of power. So, too, do processes of collective choice that produce joint action. We believe that our circumscribed conception is preferable for two reasons. It better reflects conventional understandings insofar as most scholars interested in power are concerned not simply with how effects are produced, but rather with how these effects work to the advantage of some and the disadvantage of others. We also believe that a focus on differential effects on actor capacities is, empirically, closer to the mark in most social relations. There are moments of completely voluntary persuasion and collective choice, but they are certainly rare and, on close inspection, likely to have uneven effects.

This definition informs our argument that conceptual distinctions of power should be represented in terms of two analytical dimensions that are at the core of the general concept: the kinds of social relations through which power works; and the specificity of social relations through which effects on actors' capacities are produced. The first dimension-kinds-refers to the polar positions of social relations of interaction and social relations of constitution. Accordingly, power is either an attribute of particular actors and their interactions or a social process of constituting what actors are as social beings, that is, their social identities and capacities. It can operate, for example, by pointing a gun and issuing commands, or in underlying social structures and systems of knowledge that advantage some and

10. See Isaac 1987, 75-77; Hayward 2000, 8; and Giddens 1979, 88.

11. This definition slightly amends Scott 2001, 1-2, by pointing explicitly to the operation of power through social relations.

12. Oppenheim 1981 
disadvantage others. The second dimension-specificity-concerns the degree to which the social relations through which power works are direct and socially specific or indirect and socially diffuse. It can operate, for example, at the very instant when the gun is brandished, or through diffuse processes embedded in international institutions that establish rules determining who gets to participate in debates and make decisions.

These two dimensions generate our taxonomy of four types of power. ${ }^{13}$ Effective taxonomic exercises must try to "carve nature at its joints" to derive critical, mutually exclusive, and exhaustive distinctions. ${ }^{14}$ Toward this end, in the first section below we present our attempt to carve power at its joints. The first type is power as relations of interaction of direct control by one actor over anotherCompulsory Power; the second is the control actors exercise indirectly over others through diffuse relations of interaction-Institutional Power; the third is the constitution of subjects' capacities in direct structural relation to one anotherStructural Power; and the fourth is the socially diffuse production of subjectivity in systems of meaning and signification-Productive Power. These different conceptualizations provide distinct answers to the fundamental question: in what respects are actors able to determine their fate, and how is that ability limited or enhanced through social relations with others?

Our taxonomy of power offers several advantages for scholars of international relations theory. First, because it is founded on an explicit and logically systematic decomposition of the general concept of power, it is able to detach discussions of power from the limitations of realism and to encourage scholars to see power's multiple forms. Realism's prominence has contributed to a situation in which scholars are often asked to choose a realist formulation to the neglect of an alternative, or vice versa. ${ }^{15}$ Those who want to expand the conceptualization of power frequently pose theirs as a supplement or an alternative to the realist benchmark. Nye, for example, offers his concept of "soft power" as a counterpoint to the realist emphasis on "hard power." 16 Gruber's concept of "go-it-alone power" is a modification of realist-influenced approaches. ${ }^{17}$ Although these statements use-

13. Our taxonomy bears some resemblance to, but is distinct from, the conventional "four faces" approach to power because, we contend, ours is analytically more systematic and precise, and conceptually more general. Digeser nicely summarizes the differences among the four faces in the following way: "Under the first face of power the central question is, 'Who, if anyone, is exercising power?' Under the second face, 'What issues have been mobilized off the agenda and by whom?' Under the radical conception, 'Whose objective interests are being harmed?' Under the fourth face of power the critical issue is, 'What kind of subject is being produced?'" Digeser 1992, 980. For other summaries of these faces, see Hayward 2000, chap. 1; and Hay 1997. Because the four faces developed sequentially through a progressive debate about gaps and absences in prior conceptions, they are not elements in a systematic typology. There are no analytical dimensions that distinguish across all four faces, and the faces overlap and blur into one another.

14. Hempel 1952 and 1965.

15. Classic texts include Carr 1964; Morgenthau 1967; Knorr 1973; and Claude 1962.

16. Nye $1990 ; 2002$.

17. Gruber 2000. 
fully expand the scope of the concept, their posing as an alternative to a realist formulation presumes that scholars must choose sides. Because our taxonomy alerts scholars to the fact that multiple forms of power are simultaneously present in international politics, it discourages a presumptive dismissal of other conceptual forms.

Second, our approach provides a framework for integration. Taxonomies not only highlight distinct types but also point to connections between them. In other words, the different types should not be seen as necessarily competing concepts, but rather as different forms in which power works in international politics. Our framework, therefore, suggests how scholars might consider how productive power makes some instances of compulsory power possible and legitimate, and, in turn, how compulsory power shapes the terms of meaning that influence how actors see what is possible and desirable.

Third, our approach represents a decisive advantage over recent contributions to the debate about power in international relations because it incorporates both social relations of interaction and constitution, that is, both "power over" and "power to." Baldwin's influential contributions have relied heavily on a Dahlian formulation-in which A exercises influence over B-and then attempt to incorporate a variety of concerns, including unintended effects and nonmaterial means of influence. ${ }^{18}$ Although we agree with him on many points, a fundamental problem is that his actor-oriented approach is incapable of recognizing social relations of constitution and how power inheres in structures and discourses that are not possessed or controlled by any single actor. In a series of important articles, Guzzini has urged international relations scholars to expand their understanding of power. ${ }^{19}$ Although our approaches overlap, they nevertheless differ in two important respects. First, he insists that power be reserved for moments when an actor intentionally produces effects, and that constitutive arguments be understood as "governance." ${ }^{20}$ We believe that by limiting power to those effects that are intentionally produced, he unnecessarily overlooks the important ways in which effects on the capacities and courses of action available to actors are unintentionally produced through social relations. Also, by treating power as an "agent concept" and creating a new concept, "governance," for those "effects not due to a particular agent," he establishes a false dichotomy. ${ }^{21}$ Governance necessarily entails power; the two are not in conceptual opposition. Our taxonomy, therefore, provides a systematic way of thinking about power in terms of both agency and structure, and thus allows us to incorporate the two elements of his argument in a single integrated conceptual framework.

Last, but hardly least, our taxonomy does not map precisely onto different theories of international relations. To be sure, each theoretical tradition does favor an

18. See Baldwin 1980, 1989, and 2002.

19. See Guzzini 1993, 2000, and 2002.

20. Guzzini 1993.

21. Ibid., 443. 
understanding of power that corresponds to one or another of the concepts distinguished by our taxonomy. For instance, as noted above, realists work with versions that correspond to compulsory power, and critical theorists typically work with versions that correspond to structural or productive power. But, as we show, it need not be this way. Scholars can and should draw from various conceptualizations of power that are associated with other theoretical schools. We believe that such poaching and cross-fertilization is healthy, needed, and might, in a small way, help scholars move away from perpetual rivalry in disciplinary "ism" wars and toward dialogue across theoretical perspectives.

In the second section we briefly illustrate why attention to the multiple forms of power affects empirical research through reference to two domains of contemporary theoretical significance-global governance and the debate over American empire. As scholars continue to consider power in international politics, they would do well not to fixate on a single rendition but instead to appreciate how the range of conceptualizations provides the basis for a better, richer, and fuller understanding of the workings of world politics. We conclude on this theme, briefly discussing how such cross-fertilization builds bridges between these concepts, and how scholars might think about the possible relationships.

\section{Conceptualizing Power}

Power is the production, in and through social relations, of effects on actors that shape their capacity to control their fate. This concept has two dimensions at its core: (1) the kinds of social relations through which actors' capacities are affected (and effected); and, (2) the specificity of those social relations. Conventionally for social theorists, social relations can be viewed as being broadly of two kinds: relations of interaction among previously constituted social actors; or relations of constitution of actors as particular kinds of social beings. For the second dimension, the crucial distinction is whether the social relations of interaction or constitution through which power works are direct and specific, or indirect and socially diffuse. Below we explore each dimension, then show how the polar positions within each dimension combine to generate our taxonomy of power.

\section{How Power Is Expressed: Interaction or Constitution}

The first dimension concerns whether power works in interactions or social constitution. One position on this dimension treats social relations as comprised of the actions of preconstituted social actors toward one another. Here, power works through behavioral relations or interactions, which, in turn, affect the ability of others to control the circumstances of their existence. In these conceptions, power nearly becomes an attribute that an actor possesses and may use knowingly as a resource to shape the actions or conditions of action of others. 
The other position consists of social relations of constitution. Here, power works through social relations that analytically precede the social or subject positions of actors and that constitute them as social beings with their respective capacities and interests. Constitutive relations cannot be reduced to the attributes, actions, or interactions of pregiven actors. Power, accordingly, is irreducibly social. In other words, constitutive arguments examine how particular social relations are responsible for producing particular kinds of actors. As Wendt puts it, "Constitutive theories ... account for the properties of things by reference to the structures in virtue of which they exist." 22 Because these social relations, in effect, generate different social kinds that have different self- (and other-) understandings and capacities, they have real consequences for an actor's ability to shape the conditions and processes of its existence.

This conceptual distinction between power working through social relations of interaction or in social relations of constitution tracks fairly closely with a distinction that frequents the literature on power: "power over" and "power to." Concepts of power rooted in behavior and interaction point to actors' exercise of control over others; they are, then, "power over" concepts. Concepts of power tied to social relations of constitution, in contrast, consider how social relations define who the actors are and what capacities and practices they are socially empowered to undertake; these concepts are, then, focused on the social production of actors' "power to." Some scholars, who examine how constitutive relations make possible certain types of action, focus on how community or collective action are facilitated, while others stress how the social relations of constitution can have a disciplining effect and therefore lead to self-regulation and internalized constraints. ${ }^{23}$ In either case, though, the concern is with the effect of social relations of constitution on human capacity.

This interaction/constitutive distinction also foregrounds particular features of the effects of power. Because power is a property of actors' actions and interactions in behavioral conceptions, there is a strong tendency to see its effects primarily in terms of the behavior of the object of power. In contrast, constitutive power is generally seen as producing effects only in terms of the identities of the occupants of social positions. We want to stress, though, that there is no ontological or epistemological reason why scholars working with one of those concepts need exclude the effects identified by the other. If power works through the actions of specific actors in shaping the ways and the extent to which other actors exercise control over their fate, it can have a variety of effects, ranging from directly affecting the behavior of others to setting the terms of their very self-understandings; behavioral power, then, can have effects on actors' subjectivities and selfunderstandings. Similarly, if power is in social relations of constitution, it works

22. Wendt $1998,105$.

23. For the former, see Arendt 1959; Habermas 1986; and Barnes 1988. For the latter, see Foucault 1995; Isaac 1987; and Hayward 2000. 
in fixing what actors are as social beings, which, in turn, defines the meaningful practices in which they are disposed to engage as subjects; constitutive power, then, has effects on behavioral tendencies. Thus scholars examining power through social interaction can see effects on social identities, and those examining power through constitutive relations can see effects on action.

\section{The Specificity of Social Relations of Power: Direct or Diffuse}

The second core analytical dimension concerns how specific-direct and immediate-are the social relations through which power works. Specific relations of power entail some immediate and generally tangible causal or constitutive connection between the subject and the object, or between two subjects. Scholars working with this conception tend to presume that connections between actors are mechanistic, flush with contact, direct, or logically necessary. A consequence of this dependence on social proximity is that it becomes more difficult to observe power in operation the greater is the social distance, the lag between stimulus and effect, or the absence of logical necessity, characterizing these connections.

This approach is nicely summarized by Dahl's famous claim that there is "no action at a distance." ${ }^{24}$ Although Dahl intentionally left vague both what counts as "distance" and the meaning of "connection" between two actors, he stressed that a relation of power is knowable if and only if there is an observable and traceable connection between A and B. Consequently, while his conceptualization did not preclude the idea of power as spatially, temporally, or socially indirect or diffuse, it did work against it. But it is not only Dahl's and related behavioral conceptions that operate with a specific and direct view of power. Some constitutive analyses do so as well. For example, scholars such as Bhaskar, Giddens, and Wendt point to the structured relationship of co-constitution between social roles or structural positions (such as Marxian class categories), and how their social capacities are defined in direct and specific relation to other roles or positions. ${ }^{25}$ In this way, they identify a direct and specific relationship between the social positions, which are jointly constituted structurally. ${ }^{26}$ This is how Marxist approaches consider, for instance, the co-constitutive social relations of capital and labor in capitalism; the capitalist class structure generates distinctive social capacities and interests of the social positions of capital and labor. In general, specific relations concern the direct causal/constitutive connection between actors that are in physical, historical, or social positional proximity.

Other approaches see power in indirect and socially diffuse relations. Instead of insisting that power work through an immediate, direct, and specific relationship, these conceptions allow for the possibility of power even if the connections are

24. Dahl 1957, 204.

25. See Bhaskar 1979; Giddens 1984; and Wendt 1999.

26. Also see Isaac 1987. 
detached and mediated, or operate at a physical, temporal, or social distance. Scholars that locate power in the rules of institutions, whether formal or informal, frequently trace its operation to such indirect mechanisms. Those examining concrete institutions have shown how evolving rules and decision-making procedures can shape outcomes in ways that favor some groups over others; these effects can operate over time and at a distance, and often in ways that were not intended or anticipated by the architects of the institution. ${ }^{27}$ Similarly, scholars influenced by poststructuralism examine how historically and contingently produced discourses shape the subjectivities of actors; the very reason for genealogical and discourseanalytic methods is to demonstrate how systems of knowledge and discursive practices produce subjects through social relations that are quite indirect, socially diffuse, and temporally distant. ${ }^{28}$ For instance, students of gender, race, and nation routinely recognize how socially diffuse discourses, and not isolated, direct, and proximate actions, produce the subjects of the modern world. ${ }^{29}$

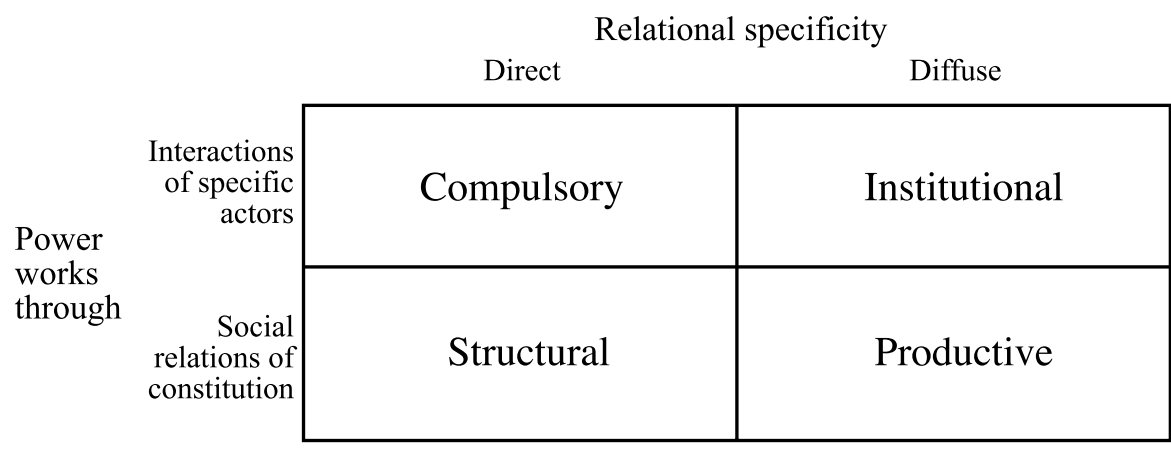

FIGURE 1. Taxonomy of power

These two core dimensions - the kinds of social relations through which power works, and the specificity of the social relations through which power's effects are produced-generate a fourfold taxonomy of power as illustrated in Figure 1. Each cell in Figure 1 represents a different conceptual type. Compulsory power exists in the direct control of one actor over the conditions of existence and/or the actions of another. Institutional power exists in actors' indirect control over the conditions of action of socially distant others. Structural power operates as the constitutive relations of a direct and specific — hence, mutually constituting — kind. Productive power works through diffuse constitutive relations to produce the situated social capacities of actors.

27. Pierson 2000.

28. See Fairclough 1992; and Kendall and Wickham 1999.

29. Kondo 1990 
Because concepts of power are partly distinguished by the conceptualized relationship between agency and structure, our taxonomy relates to the agent-structure duality to the extent that the generic concern is with the relationship between social context and human action. We want to stress, though, that because each type of power has at least an implicit view of both agency and structure, none simply reflects an entirely agentic or structural perspective (to the neglect of the other). Nevertheless, they do vary in specific ways. Compulsory (and, to a lesser degree, institutional) power emphasizes agency to the point where structure becomes the context in which A's actions and B's reactions are set and constrained, thereby leaning heavily on agency and treating structure as constraint. In contrast, concepts of structural and productive power emphasize structure relative to purposeful agency, even while recognizing that meaningful practices, and hence, human agency, are essential in producing, reproducing and possibly transforming these structures.

\section{Compulsory Power: Direct Control Over Another}

This first concept of power focuses on a range of relations between actors that allow one to shape directly the circumstances or actions of another. Some of the most famous and widely used definitions of power fall under this concept. Weber defined power as the "probability that one actor within a social relationship will be in a position to carry out his own will despite resistance, regardless of the basis on which this probability exists." ${ }^{30}$ Similarly, Blau defined it as the influence over behavior through negative sanctions. ${ }^{31}$

In terms of sheer influence, especially for scholars of international relations, arguably no definition surpasses that of Dahl's earliest formulation. ${ }^{32}$ For him, power is best understood as the ability of A to get B to do what B otherwise would not do. Dahl's concept has three defining features. One, there is intentionality on the part of Actor A. What counts is that A wants B to alter its actions in a particular direction. If $\mathrm{B}$ alters its actions under the mistaken impression that $\mathrm{A}$ wants it to, then that would not count as power because it was not A's intent that B do so. Two, there must be a conflict of desires, to the extent that B now feels compelled to alter its behavior. A and B want different outcomes, and B loses. Three, A is successful because it has material and ideational resources at its disposal that lead B to alter its actions. Although theorists have debated whether the relevant resources are an intrinsic property of actors or are better understood as part of a relationship of dependence between two or more actors, the underlying claim is that identifiable resources that are controlled and intentionally deployed by actors are what counts for thinking about power. ${ }^{33}$

30. Weber $1947,52$.

31. Blau 1964, 115-16.

32. Dahl 1957, 202-3. As Baldwin 2001, 177, claimed, "none rivals this one in widespread acceptability." Dahl modified his views in later statements. See Dahl and Stinebrickner 2003.

33. For the first claim, see Emerson 1962; Blau 1964; and Wrong 1988. For the second, see Lasswell and Kaplan 1980; and Russell 1986, 19-20. 
Although Dahl's initial conceptualization usefully illustrates the concept of compulsory power, our taxonomy highlights how compulsory power need not hinge on intentionality. ${ }^{34}$ Compulsory power is present whenever A's actions control B's actions or circumstances, even if unintentionally. As Bachrach and Baratz argue, power still exists even when those who dominate are not conscious of how their actions are producing unintended effects. ${ }^{35}$ The victims of "collateral damage" of bombing campaigns certainly experience the power of the deliverer even if it was not the latter's intention to create such damage. Because power is the production of effects, arguably compulsory power is best understood from the perspective of the recipient, not the deliverer, of the direct action.

Compulsory power has significantly influenced thinking about power in international politics. ${ }^{36}$ Specifically, its emphasis on control by identifiable actors over the objections of other actors through deployment (even if only symbolically) of resources informs much of realist thought. For many scholars-both realists and their critics-to study power in international relations is to consider how one state is able to use material resources to advance its interests in direct opposition to the interests of another state. This approach steers attention to the great powers. Yet major powers are not alone in the ability to deploy resources to overcome the objections of actors. Multinational corporations can use their control over capital to shape the foreign economic policies of developing states, as well as global economic policies. Nonstate networks and groups sometimes conduct campaigns of unconventional warfare that terrorize entire populations.

Compulsory power is not limited to material resources; it also entails symbolic and normative resources. ${ }^{37}$ Nongovernmental organizations have deployed normative resources to compel targeted states to alter their policies through a strategy of shaming. ${ }^{38}$ Drawing from the work of Goffman and Bourdieu, Barnett argued that Arab states have used symbolic sanctions to alter the behavior of other Arab states on a range of issues. ${ }^{39}$ Less powerful members of the Security Council are able to use legal norms to constrain the actions of the powerful. ${ }^{40}$ International organizations are able to use their expert, moral, delegated, and rational-legal authority as a resource to compel state and nonstate actors to change their behavior. ${ }^{41}$

In general, scholars should be attentive to a range of technologies and mechanisms as they consider how one actor is able to directly control the conditions of behavior of another actor. In fact, there is a long pedigree for doing just that. Carr began this tradition when he distinguished between military, economic, and propa-

34. On this point we agree with Baldwin 2002, and disagree with Guzzini 1993.

35. Bachrach and Baratz 1962, 952.

36. See Claude 1962; Knorr 1973; and Baldwin 1989 and 2002. For a discussion and critique of power-centered analysis, see Vasquez 1998; and Guzzini 1993 and 1998.

37. Baldwin 2002, 178-79.

38. See Keck and Sikkink 1998; and Risse et al. 1999.

39. Barnett 1998.

40. Johnstone 2003.

41. Barnett and Finnemore 2004. 
ganda power, corresponding respectively to the threatened or actual deployment of violence, nonviolent sanctions, and normative pressure. ${ }^{42}$ These distinctions do usefully refine one's understanding of how compulsory power works, but from the perspective of our taxonomy these are refinements of a specific concept of power, compulsory power, and not distinct concepts, per se.

\section{Institutional Power: Actors' Control Over Socially Distant Others}

Whereas compulsory power entails the direct control of one actor of the conditions and actions of another, institutional power is actors' control of others in indirect ways. Specifically, the conceptual focus here is on the formal and informal institutions that mediate between $\mathrm{A}$ and $\mathrm{B}$, as $\mathrm{A}$, working through the rules and procedures that define those institutions, guides, steers, and constrains the actions (or nonactions) and conditions of existence of others. ${ }^{43}$

Thus compulsory and institutional power differ in the following ways. To begin, whereas compulsory power typically rests on the resources that are deployed by A to exercise power directly over B, A cannot necessarily be said to "possess" the institution that constrains and shapes B. It is certainly possible that a dominant actor maintains total control over an institution, which, in turn, lords over other actors. If so, then it is arguably best to conceptualize the institution as possessed by the actor, that is, as an instrument of compulsory power. But rare is the institution that is completely dominated by one actor. Instead, it is much more likely that an institution has some independence from specific resource-laden actors. ${ }^{44}$ This provides the principal analytical grounds for making the move to the institutional context.

Second, the recognition of the importance of institutional arrangements highlights that A and B are socially removed from-only indirectly related to-one another. This distance can be spatial or temporal. Spatially, A's actions affect the behavior or conditions of others only through institutional arrangements (such as decisional rules, formalized lines of responsibility, divisions of labor, and structures of dispersed dependence); power is no longer a matter of A's direct effect on $\mathrm{B}$, but works instead through socially extended, institutionally diffuse relations. In other words, A does not "possess" the resources of power, but because A stands in a particular relation to the relevant institutional arrangements, its actions exercise

42. Carr 1964.

43. We caution against two possible, but inapt, connotations of institutional power: the power of institutions as actors in their own right (for example, the World Bank's power over borrowing countries); and the effect of institutions in constituting social subjects (for example, the institution of sovereignty affects the constitution of state subjects). The former is best understood as compulsory power and the latter as either structural or productive power. Institutional power, in other words, does not include any and all aspects of power by, in, and through institutions. Instead, it is preconstituted actors exercising control over others indirectly through institutions.

44. See Abbott and Snidal 1999; and Barnett and Finnemore 2004. 
power over B. Temporally, institutions established at one point in time can have ongoing and unintended effects at a later point. Long-standing institutions represent frozen configurations of privilege and bias that can continue to shape the future choices of actors. Third, analyses of institutional power necessarily consider the decisions that were not made (the proverbial dogs that do not bark) because of institutional arrangements that limit some opportunities and bias directions, particularly of collective action. ${ }^{45}$ Institutional arrangements can shape the agendasetting process in ways that eliminate those very issues that are points of conflict.

International relations scholars have developed a range of arguments that examine how formal and informal institutions enable some actors to shape the behavior or circumstances of socially distant others. The literature on formal and informal agenda setting focuses on who sets the agenda and how that agenda omits certain possibilities. ${ }^{46}$ Also of relevance is the literature that highlights traditional notions of dependence; that is, how material processes limit the choices available to dependent actors. Hirschman, for example, famously argued that market forces can create dependent relationships that limit the weaker actor's choices. ${ }^{47}$ Along similar lines, Keohane and Nye considered how enduring systems of exchange and interdependence can be media of power. ${ }^{48}$

Also prominent here are neoliberal institutional approaches that focus on the behavioral constraints and governing biases of institutions. The general concern is with durable solutions to games of interdependent choice and how institutions help to solve coordination and cooperation dilemmas. Yet the institutional rules that establish a particular focal point also serve to generate unequal leverage in determining collective outcomes. In short, the institutions that are established to help actors achieve mutually acceptable, even Pareto-superior, outcomes also create "winners" and "losers," to the extent that the ability to use the institution and, accordingly, collective rewards-material and normative-are unevenly distributed long into the future and beyond the intentions of the creators. ${ }^{49}$ Indeed, many scholars examining how international institutions look from the vantage point of the weak tend to stress those very features. ${ }^{50}$

\section{Structural Power: Direct and Mutual Constitution of the Capacities of Actors}

Structural power concerns the structures-or, more precisely, the co-constitutive, internal relations of structural positions-that define what kinds of social beings

45. Bachrach and Baratz 1962 and 1963. Compulsory power, too, can entail "nondecision." For example, failing even to consider the possibility of distributing certain medications to populations in dire need of them can be a form of direct control of A over B.

46. See Mansbach and Vasquez 1981; Krasner 1985; and Pollack 2003.

47. Hirschman 1945. Aspects of Hirschman's argument, of course, emphasize direct relations of dependence between two countries, and hence, compulsory power.

48. Keohane and Nye 1977. See also Baldwin 1980; and Caporaso 1978.

49. See Krasner 1991; Gruber 2000; Goldstein 1989; and Garrett and Tsebelis 1999.

50. See Murphy 1984; and Ayoob 1995, chap. 7. 
actors are. It produces the very social capacities of structural, or subject, positions in direct relation to one another, and the associated interests, that underlie and dispose action. This makes this type of power quite different from institutional power. Whereas institutional power focuses on differential constraints on action, structural power concerns the determination of social capacities and interests. This important difference owes chiefly to their different theoretic understandings of structure. Scholars focusing on institutional power usually define institutions and structure in almost interchangeable terms, as sets of rules, procedures, and norms that constrain the action of already-constituted actors with fixed preferences. Scholars focusing on structural power conceive structure as an internal relation-that is, a direct constitutive relation such that the structural position, A, exists only by virtue of its relation to structural position, B. ${ }^{51}$ The classic examples here are masterslave and capital-labor relations. From this perspective, the kinds of social beings that are mutually constituted are directly or internally related; that is, the social relational capacities, subjectivities, and interests of actors are directly shaped by the social positions that they occupy.

Structural power shapes the fates and conditions of existence of actors in two critical ways. One, structural positions do not necessarily generate equal social privileges; instead structures allocate differential capacities, and typically differential advantages, to different positions. Capital-labor and master-slave relations are obvious examples of how social structures constitute unequal social privileges and capacities. Two, the social structure not only constitutes actors and their capacities, it also shapes their self-understanding and subjective interests. The consequence is that structures that distribute asymmetric privileges also affect the interests of actors, often leaving them willing to "accept their role in the existing order of things." ${ }^{52}$ In other words, structural power can work to constrain some actors from recognizing their own domination. To the degree that it does, actors' selfunderstandings and dispositions for action serve to reproduce, rather than to resist, the differential capacities and privileges of structure. As Steven Lukes observed: "is it not the supreme and most insidious exercise of power to prevent people, to whatever degree, from having grievances shaping their perceptions, cognitions, and preferences in such a way that they accept their role in the existing order of things?" ${ }^{53}$ In this way, structural power operates even when there are no instances of $\mathrm{A}$ acting to exercise control over B. ${ }^{54}$

Various international relations scholars forward arguments that have strong shades of structural power. Most obviously, Marxist-influenced scholars gravitate toward

51. See Bhaskar 1979; and Isaac 1987.

52. Lukes 1975, 24.

53. Ibid. It is possible to construct a compulsory power answer to this question. For instance, A might act to alter the beliefs of $\mathrm{B}$, thereby making it easier to control $\mathrm{B}$, as it is always easier to maintain a social order through consent than through coercion. Baldwin 2002, 179, gives the example of brainwashing. Related is Hurrell and Woods's 1995 concept of coercive socialization and Ikenberry and Kupchan's 1990 notion of hegemonic power.

54. This approach relates to the distinction between objective and subjective interests. See Benton 1981. 
this concept. ${ }^{55}$ Explicitly following Lukes and Gramsci, Gill and Law argue that while power exists in coercion and institutional arrangements, to understand the workings of the global capitalist economy requires recognition of global production relations as constitutive structure ${ }^{56}$ For them, as well as other Gramscians and historical materialists, the structure of global capitalism substantially determines the capacities and resources of actors. ${ }^{57}$ It also shapes their ideology—that is, the interpretive system through which they understand their interests and desires. This ideology, according to scholars like Gill and Law, is hegemonic in that it serves the objective interests of the capitalists and their fellow travelers at the direct expense of the objective (but not, then, recognized) interests of the world's producing classes, thereby disposing action toward the reproduction, rather than the substantial transformation, of the structure and its relations of domination. In the same spirit, Cox draws on Machiavelli's notion of power as a centaur: it operates overtly to the extent that one actor will manipulate strategic constraints for the purposes of controlling the actions of actors (the beast of compulsory and institutional power), and it operates covertly to the extent that it generates the social powers, values, and interpretations of reality that deeply structure internal control (the man that is structural power)..$^{58}$ World-systems theorists also draw on this conception of power to the extent that they argue that: structures of production generate particular kinds of states identified as core, semiperiphery, and periphery; the positions in the world-system generate commensurate sets of identities and interests; and those in the subordinate positions adopt (ideologically generated) conceptions of interest that support their own domination and their lesser position in that world-system..$^{59}$

Because many constructivists draw from structurally oriented theories of sociology, they also are sometimes attentive to structural power. Wendt, for instance, argues that "a key aspect of any cultural form is its role structure, the configuration of subject positions that shared ideas make available to its holders." ${ }^{60} \mathrm{He}$ proceeds to note that the role structures can contain functional differentiation and thus generate differential privileges and capacities to the occupants of these roles. ${ }^{61}$ Although constructivists who draw from sociological institutionalism do not usually adopt a notion of structure as a set of internal relations, they make a related conceptual move, suggesting a hint of structural power, to the extent that rules, which often are associated with and can generate roles, produce the identities and interests of actors. ${ }^{62}$ This tendency is especially evident among those associated

55. Marxists are not alone in emphasizing structural power. Bourdieu 2001 focuses on the global importance of masculine domination produced through the structure of patriarchy. Strange 1989 developed a non-Marxian approach to what she calls structural power.

56. Gill and Law 1989.

57. Rupert and Smith 2002.

58. Cox 1992.

59. Wallerstein 1996.

60. Wendt 1999, 257.

61. Also see Wendt and Duvall 1989.

62. Finnemore 1996. 
with the world polity school. Boli and Thomas, for instance, argue that there is a world authority structure, a set of fundamental principles, that constitutes who are the actors of world politics, what are their identities, what are their expressive purposes, and what are their differential capacities. Consequently, they argue that the institutionalization of a world authority structure that is organized around rational-legal values increasingly privileges the voices of international nongovernmental organizations. ${ }^{63}$

\section{Productive Power: Production of Subjects Through Diffuse Social Relations}

Productive power and structural power overlap in several important respects. Both are attentive to constitutive social processes that are, themselves, not controlled by specific actors, but that are effected only through the meaningful practices of actors. Both concern how the social capacities of actors are socially produced, and how these processes shape actors' self-understandings and perceived interests. Additionally, neither concept of power depends on the existence of expressed conflict (although resistance is at the heart of the dynamics of change of them).

Yet structural and productive power differ in a critical respect: whereas the former works through direct structural relations, the latter entails more generalized and diffuse social processes. Specifically, and at the risk of gross simplification, structural power is structural constitution, that is, the production and reproduction of internally related positions of super- and subordination, or domination, that actors occupy. Productive power, by contrast, is the constitution of all social subjects with various social powers through systems of knowledge and discursive practices of broad and general social scope. Conceptually, the move is away from structures, per se, to systems of signification and meaning (which are structured, but not themselves structures), and to networks of social forces perpetually shaping one another. In that respect, attention to productive power looks beyond (or is post-) structures.

This difference between direct and diffuse social relations of constitution has two important implications for thinking about productive power. First, productive power concerns discourse, the social processes and the systems of knowledge through which meaning is produced, fixed, lived, experienced, and transformed. ${ }^{64}$ Discourses are understood here not as dialogues among specific actors or in terms of Habermasian notions of communicative action. Instead, the concept refers to how "microfields" or the quotidian "define the (im)possible, the (im)probable, the natural, the normal, what counts as a problem." ${ }^{65}$ In this way, discourses are sites 
of social relations of power because they situate ordinary practices of life and define the social fields of action that are imaginable and possible. ${ }^{66}$

Second, discursive processes and practices produce social identities and capacities as they give meaning to them. In Foucault's archetypical formulation, humans are not only power's intended targets, but also its effects. ${ }^{67}$ Discourse, therefore, is socially productive for all subjects, constituting the subjectivity of all social beings of diverse kinds with their contingent, though not entirely fluid, identities, practices, rights, responsibilities, and social capacities. ${ }^{68}$ Productive power, therefore, differs from structural power in its approach to subjectivity. Because structural power concerns the co-constitution of subjects, it typically envisions hierarchical and binary relations of domination that work to the advantage of those structurally empowered, to the disadvantage of the socially weak. In contrast, productive power concerns the boundaries of all social identity, and the capacity and inclination for action for the socially advantaged and disadvantaged alike, as well as the myriad social subjects that are not constituted in binary hierarchical relationships. ${ }^{69}$ Productive power, in this way, refuses

to assume that some essence is at the root of human subjectivity, [and raises] the possibility that every ordering of social relations, and every ordering of social selves (every inter- and intrasubjective power relation) bears some cost in the form of violence it does to "what it might be 'in the self and in the social world. " 70

In general, the bases and workings of productive power are the socially existing and, hence, historically contingent and changing understandings, meanings, norms, customs, and social identities that make possible, limit, and are drawn on for action. $^{71}$

Some of the best examples of the analysis of productive power in international relations refer to the discursive production of the subjects, the fixing of meanings, and the terms of action, of world politics. One question concerns the kinds of subjects that are produced. Basic categories of classification, like "civilized," "rogue," "European," "unstable," "Western," and "democratic" states, are representative of productive power, as they generate asymmetries of social capacities. ${ }^{72}$ Even categories such as "weapons of mass destruction" can evolve in unexpected ways and stabilize meanings that constrain policy. ${ }^{73}$ A related theme is how the "other" comes to be defined and how that definition is associated with

66. See Foucault 1984 and 1983.

67. Foucault 1971, 170.

68. Butler 1999.

69. For a range of statements that address these differences, see Ball 1992; Barnes 1988; Benton 1981; Wartenberg 1992; and Isaac 1987.

70. Hayward 2000, 6 (emphasis in the original).

71. Ibid., 30.

72. See Doty 1996; and Inayatullah and Blaney 2003.

73. See Litwak 2002; and The New Republic, 7 October 2002, 22. 
the practices and policies that are possible, imaginable, permissible, and desirable. ${ }^{74}$ Also, socially contested efforts to set and fix meanings can be expressive of productive power. ${ }^{75}$ A particular discourse of development orients action in one direction and away from others. ${ }^{76}$ The gendered categories of "civilian" and "combatant" in international humanitarian law have real consequences for those on the ground, protecting some while putting others at the risk of death. ${ }^{77}$ Thus to attend to the analysis of productive power is to focus on how diffuse and contingent social processes produce particular kinds of subjects, fix meanings and categories, and create what is taken for granted and the ordinary of world politics.

\section{Governance and Empire}

The four concepts of power offer distinctive views about how actors' abilities to shape and set the conditions of their existence and action are affected and effected in international relations. Although each concept offers important insights into how power operates, a full accounting of power requires a consideration of its multiple forms operating in relation to each other. Our taxonomy does more than alert scholars to the different forms of power, though, for it also encourages a consideration of their conjunction. To demonstrate the value of our taxonomy for seeing the distinctive forms and the linkages between them, we consider two major issues in global politics-global governance, and American empire.

\section{Global Governance}

Scholars of global governance often define it as the institutionalized coordination or collaboration of people's and states' activities in ways that achieve more desirable-positive sum - outcomes. ${ }^{78}$ Because of this tendency to tie global governance to institutionalized cooperation, coordination of convergent interests, and the production of collective goods, many scholars diminish or overlook the role of power. ${ }^{79}$ Yet governance is part of a family of concepts, including control, guidance, and steering, which are also elements of the family of "power" concepts. Therefore, the scholarly tendency to slight how power operates in global governance is conceptually and theoretically problematic. Power is central to global governance, and our taxonomy highlights the multiple and interconnected ways in which it operates.

74. See Campbell 1992; and Neumann and Welsh 1991.

75. See Williams 1996; and Neumann 1999.

76. See Ferguson 1994; and Sen 1999.

77. See Carpenter 2003; and Kinsella 2003.

78. See Commission on Global Governance 1995, 2; Young 1994, 53; and Gordeneker and Weiss 1996, 17.

79. This argument is developed in Hurrell 2005. 
International institutions, formal and informal, are often understood to be at the heart of global governance. Relations of cooperation and coordination, practices of international law, and the processes of collective action that they entail, are effected in and through institutions. Institutional power thus provides a reasonable conceptual starting point for examining power in global governance, and shapes global governance in at least three ways.

First, any concern with global governance must consider what issues are of concern and which issues are not. For decades after World War II, issues of human rights, women's rights, and children's rights never made it on the UN agenda and thus were never discussed or even deemed worthy of "governance." That is no longer the case. ${ }^{80}$ Today, issues of collective responsibility for adequate employment or a livable wage for all people are institutionally excluded. One major goal of proponents of the new international economic order (NIEO) was to transform the issues that were debated and regulated in the global economy. ${ }^{81}$ Agendas enable some actors to further their interests and ideals, to exercise control over others, and to limit the abilities of actors to engage in effective collective action.

Second, a consideration of institutional power also exposes the governing biases of institutions. As we noted in the conceptual discussion above, the institutional rules that establish a particular focal point also serve to generate unequal leverage or influence in determining collective outcomes. ${ }^{82}$ In short, the institutions that are established to help actors achieve pareto-superior outcomes also create "winners" and "losers," to the extent that the ability to use the institution and, accordingly, collective rewards are unevenly distributed. ${ }^{83}$ This institutional context, moreover, lingers into the future, thus constraining action in ways that might not have been intended but nevertheless limit choice and shape action. ${ }^{84}$ This is precisely the point of considerable contemporary criticism of a number of formal organizations involved in governing the global economy, such as the World Trade Organization (WTO) and the International Monetary Fund (IMF). ${ }^{85}$ Recent analyses of the international refugee regime also have noted how legal and normative changes have potentially come at the expense of refugees. ${ }^{86}$

Third, also consistent with the biases of institutions is the ability of great powers to establish international institutions and arrangements to further or preserve their interests and positions of advantage into the future, even as they do not directly or fully control those future arrangements. Gruber's concept and application of "go-it-alone" power suggests how strong states undertake a course of action that subsequently shapes future outcomes for others, and that weak states go along

80. See Joachim 2003; and Clark, Friedman, and Hochstetler 1998.

81. See Murphy 1984; and Krasner 1985.

82. Knight 1992, 131-36.

83. See Krasner 1991; and Gruber 2000.

84. Goldstein 1989.

85. See Kapstein 1999; and Shaffer 2005.

86. Loescher 2001. 
with an agreement that may actually leave them worse off, because to oppose the inevitable will only cost them more in the long run. ${ }^{87}$ In short, for Gruber, weaker states are damned if they do and doubly damned if they do not. Significantly, it is less important that the outcome is willfully intended than that is an effect of asymmetrical ability to shape the context of choice or decision. Strange argued that while American power as defined by material resources might be in decline (at the time of her writing), the United States is the epicenter of a transnational empire that gives it the ability to shape security, financial, productive, and knowledge structures, which, in turn, operate to U.S. advantage and foreclose opportunities to other countries. ${ }^{88}$ Ikenberry has argued that liberal great powers have attempted to use their positions of power after war to establish international governance mechanisms that simultaneously preserve and diffuse their power. ${ }^{89}$ In sum, the institutional core of global governance, while seemingly resting on the production of joint gains through cooperation or coordination, also entails the substantial operation of institutional power.

But institutional power, alone, does not tell the whole story. The example of great powers attempting to shape institutions suggests more traditional senses of "power struggles," which directs attention to compulsory power. Here, most obviously, the concern is with how states, and largely the great powers, are able to determine the content and direction of global governance by using their decisive material advantages not only to determine what areas are to be governed, but also to directly "coordinate" the actions of lesser powers so that they align with their interests. ${ }^{90}$ Other examples of this form of power include the U.S. efforts to determine the terms of the International Criminal Court by manipulating incentives for particular targeted states, and the special relationship established between European states and some of their former colonies with respect to international trade regime provisions.

States, though, are not the only actors that have the ability to set and enforce the rules of global governance in ways that directly control the actions of others. International organizations sometimes do too, as they can be not only sites of institutional power through which other actors indirectly exercise control but also can exhibit compulsory power. ${ }^{91}$ The World Bank's considerable potential for compulsory power vis-à-vis borrowing states with respect to "development policy" is illustrative. The UN High Commission on Refugees (UNHCR) can shape the life chances of refugees and other displaced peoples. ${ }^{92}$ It is partly because of the recognition of the concentration of such resources for compulsory power in international organizations that many scholars and policymakers argue for a decon-

87. Gruber 2000.

88. Strange 1989.

89. Ikenberry 2001.

90. Gilpin 2002.

91. Barnett and Finnemore 2004.

92. Harrell-Bond 2002. 
centration of decisional authority, a substantial democratization of the institutions of global governance, or mechanisms of accountability. ${ }^{93}$

Even some materially challenged actors are able to exercise compulsory power in global governance processes. Transnational activists, civil society organizations, and international nongovernmental organizations have demonstrated the ability to use rhetorical and symbolic tools, as well as shaming tactics, to get states, multinational corporations, and others to comply with the values and norms that they advance. ${ }^{94}$ Various transnational activists successfully used symbolic means to press the Clinton administration to sign the landmine treaty. ${ }^{95}$ Activists have formed associations and deployed branding and certification techniques to try to use consumer power to compel producers to comply with labor, environmental, and human rights standards. ${ }^{96}$

Analysis of global governance needs to be attentive not only to the interactions of actors but also to the constitutive reproduction of the subjects of global social life. Gramscians and historical materialists have examined how global institutions help to stabilize and spread global governance that has a markedly liberal and capitalist character. ${ }^{97}$ Also prominent here are studies that examine the mutually constituted structural relations of capital and labor-and of core and periphery-in global activities of material production, and how these structures generate a global distribution of material well-being and organize the mechanisms that facilitate, reproduce, regulate, and guard that distribution. ${ }^{98}$ The actual workings of global governance, in this view, are reflective of the underlying global class structure, and the ideologies of global governance help to reproduce that structure by fostering a worldview among the exploited classes that either there is no alternative or the current social order is desirable. ${ }^{99}$

The concept of productive power as applied to global governance highlights how the discourses and institutions of international relations contingently produce particular kinds of actors with associated social powers, self-understandings, and performative practices. Consider the Global Compact, which "engages the private sector to work with the UN, in partnership with international labor and nongovernmental organizations (NGOs), to identify, disseminate, and promote good corporate practices based on nine universal principles" that are found in various UN documents. ${ }^{100}$ Because this ambitious agenda is undertaken by a slimly funded and staffed unit attached to the secretariat-general's office, it is not an obvious place to look for evidence of power, even if the goal is to alter corporate practices.

93. See Stiglitz 2002; Dahl 2003; Keohane and Nye 2003; and Wellens 2002.

94. Keck and Sikkink 1998.

95. Price 1998.

96. Broad 2002.

97. See Murphy 1994; Cox 1992; Latham 1999; and Rupert and Smith 2002.

98. Wallerstein 1998.

99. Rupert 2000.

100. Ruggie 2001, 371-72. 
Yet the architects of the Global Compact imagine two distinctive mechanisms that might foster this development, and these mechanisms are expressions of productive power. One, as multinational corporations sign onto a set of (evolving) standards and practices, a discursive space is opened in which various actors are produced as subjects empowered legitimately to comment on their performance. Those actors are thereby given social resources that enable them effectively to exercise the compulsory power of shaming corporations into changing their behavior. Additionally, the discourse of the Global Compact also aspires to create a new kind of actor-the potentially "socially responsible corporation"- that may adhere to these best practices not because of the manipulation of incentives, but rather because of a new self-understanding. ${ }^{101}$ In other words, the discourse is intended to produce a new "social kind" that will be self-regulating and self-disciplining. The production of this new social kind is hypothesized to occur through various mechanisms. To begin, they are expected to translate pertinent UN principles, which are legitimated by the international community and draw from broader discourses of liberalism, into lessons learned that can be transformed into best practices. To encourage this process, the Global Compact has created a learning network that, ultimately, is "intended to stimulate the internationalization of UN principles into companies' corporate cultures." 102 This lengthy process will depend on the willingness of corporations to adopt new texts, business models, and practices that ultimately become internalized and identified with the performance of this new social identity, the socially responsible corporation. The Global Compact, therefore, illuminates the workings of, and connections between, different forms of power: compulsory power because of the ability of nonstate actors to deploy shaming techniques to alter corporate practices; institutional power because of the role of the UN in establishing new rules that can constrain the behavior of corporations; and productive power because of the attempt to help produce a new social kind of corporate actor.

The productive power of the Global Compact discourse, although important in its own right, is merely illustrative of the broad significance of productive power in global governance. Indeed, all practices of guiding and steering collective outcomes in global social life, with the possible and partial exception of instances of compulsory power effected through relations of raw coercive force and violence, derive from discourses that are productive of the social identities of the actors engaged in them. The human rights regime, for example, is an expression of a discursively constituted world populated by subjects normalized as human rights victims, human rights monitors, human rights violators, and human rights prosecutors. To analyze global governance processes adequately, then, it is necessary to address systematically the workings of productive power in setting the conditions of meaningful collective action.

101. Ruggie 2002.

102. Ibid. 
Understanding the operation of power in multiple forms makes it much more difficult to approach global governance purely in terms of cooperation, coordination, consensus, and normative progress. Governance is also a matter of compulsion, institutional bias, privilege, and unequal constraints on action. Although these different concepts of power illuminate different ways in which power operates in global governance, there is an important difference between the first two and the last two that affects how we think about governance: the first two concern who governs in global governance, whereas the latter two concern not who governs, but instead how the governing capacities of actors are produced, how those capacities shape governance processes and outcomes, and how bodies of knowledge create subjects that are to be, at least in part, self-regulating and disciplined. ${ }^{103}$ Our taxonomy does more than simply illuminate the different ways power operates in global governance, for it also encourages scholars to identify connections between these forms.

\section{American Empire}

If scholars of global governance have tended to underestimate the role of power in any of its forms, there is no such danger regarding the contemporary debate about the existence, nature, and consequences of U.S. empire. The U.S. response to the terrorist attacks of September 11, 2001, President George W. Bush's 2002 National Security Strategy, and the U.S. occupation of Iraq have caused scholars and pundits to debate whether the United States is an empire. ${ }^{104}$ Their evaluations frequently turn on sometimes loose, but certainly varied, usages of the concept. We do not intend to provide the definitive concept of empire and then use that concept to determine whether or not the label applies to the United States. Instead, our modest goal is to demonstrate that any systematic discussion of empire must consider power in multiple forms.

Much of the debate over the existence and nature of American empire pivots off of what we have called compulsory power. It could hardly be otherwise. A fundamental issue, after all, is the U.S.'s ability and willingness to use its overwhelming concentration of resources to shape directly the actions of others. For many observers, the decision to designate the United States as an empire rests on its apparent quest to use coercion and intimidation if and when necessary to develop and sustain its supremacy over other regions and states. The emphasis on direct control over others certainly corresponds to the concept of compulsory power, but our concept does raise questions regarding whether the designation of empire should be dependent on intentions and brass-knuckle tactics.

103. Brass 2000, 316.

104. The generic concern is with the informal or formal hierarchical arrangements that maintain the domination of one actor over others. See Shaw 2002, 331-32, and Doyle 1986 for a general discussion, and Rosen 2003 for application of the concept to the contemporary United States. 
Much of the recent discussion over the United States as an empire revolves around its intentions. After all, although the U.S. global share of material resources has not changed significantly during the past decade, what has changed, according to many, is the Bush administration's determination to use its unrivaled position to strong-arm others and to scare away possible challengers. This is one reason why much is made of the Bush administration's 2002 National Security Strategy; it appears to announce loudly and boldly its goal of maintaining an empire in form if not in name. But, should intentionality be the metric for determining the existence of empire? As we have shown, compulsory power does not hinge on intentionality; it still operates even when those who directly dominate others are not conscious of how their actions are producing unintended effects. A state that has no intention of creating or maintaining an empire, per se, might nevertheless exercise directly controlling effects that are nearly identical to those who do. To the extent that compulsory power is the key, then, evidence of empire may best be found not in the intentions of the subject but instead in the consequences as viewed from the objects of the empire.

The concept of compulsory power also questions whether the reliance on coercive means is necessary for the designation of empire. Compulsory power concerns the direct control of others, but admits for a range of technologies that allow A to control the behavior and circumstances of B. Consequently, although empires use military means, they also can be expected to use less coercive tactics. Doing so might not make them any less of an empire, a point emphasized by Carr in his discussion of the colonial empires. ${ }^{105}$ The relevance of thinking about noncoercive mechanisms is quite germane to the tendency, among some scholars, to highlight the perceived willingness of the Bush administration to forgo multilateral means in favor of unilateral instruments as evidence of the bid for empire. ${ }^{106}$ In other words, for such analysts it is the shift from a grand strategy revolving around institutional power to one founded primarily on compulsory power that best signals the new status of the United States as empire.

The backdrop to this argument is an interpretation of what accounts for the longevity of American hegemony after World War II and how it differed from previous hegemonies, including the colonial empires it supplanted. The genius of the post-World War II "wise men," in this way, was to recognize that global rule through coercion was unsustainable, and that it was preferable to establish global institutions that could further American interests and spread American values. ${ }^{107}$ What generated consent for American hegemony was not only agreement over the purpose of American power, but also the construction of multilateral institutions that were conferred legitimacy, constrained American power, and democratized the decision-making process. Because these global institutions had some

105. Carr 1964.

106. See Nye 2003; Ikenberry 2002; and Kupchan 2002.

107. Ikenberry 2001. 
autonomy from the United States and were partly controlled by other states, the United States could not be said to possess them, even though they reflected American interests. What separates American hegemony from American empire in this view, therefore, is the willingness to work jointly with others through multilateral institutions and the consent that is attended to them. ${ }^{108}$ The Bush administration's decision to shift the weight of American foreign policy from multilateral to unilateral mechanisms provides partial cause for observers to relabel the United States an imperial power.

But it is important to recognize how American hegemony, even when run through global institutions, still represented an exercise of institutional power. The absence of overt conflict does not mean the absence of power; institutions can mobilize bias to serve U.S. purposes and eliminate points of potential opposition to serve U.S. concerns. Moreover, global institutions created an asymmetrical distribution of benefits, and the United States has been a prime beneficiary. It is partly for this reason that Bacevich claims that the nature of the American empire since World War II has revolved around global institutions that create "open spaces" that the United States can dominate. ${ }^{109}$ Finally, and most importantly, the United States still exercises power, but now it is indirect and mediated through institutions. Any consideration of the American empire, in short, must be attentive to institutional power. In this respect, perhaps at stake is not whether the United States is or is not an empire, but rather whether the longevity of that empire is dependent on the willingness to eschew unilateral means of control for indirect institutional means-a point that echoes earlier debates over the nature of informal empires. ${ }^{110}$

Yet to what extent should the debate about the American empire focus exclusively on the specificity of the United States as an actor? Compulsory and institutional power directs attention to empire as an extension of a centralized, territorial state that maintains control over others, and thus focuses on the policies of the United States in general and the Bush administration in particular. Structural and productive power, however, shift the focus away from particular actors that control, directly or indirectly, others to social relations of constitution. In doing so, it directs attention to the underlying social relations that make possible an assumption of imperial power, give meaning to U.S. foreign policy practices, and imagine empire as having a decentralized, even deterritorialized, form.

To consider structural power in debating the existence or implications of U.S. empire means, first and foremost, exploring the structural constitution of the United States as imperial center. This has three interconnected aspects. First, the structure of social relations of material production are transnational and create functional and spatial differentiation between a world-economic core and periphery. Along these lines, scholars influenced by Marxism and world-system theory generally

108. Mehta 2003, 51-52.

109. Bacevich 2002.

110. Mommsen 1986. 
situate their discussions of U.S. foreign policy in the context of how global capitalism generates a particular set of social positions and practices for the United States in direct relationship to the structurally disadvantaged. ${ }^{111}$ Such a consideration frequently includes a claim that a partially deterritorialized global capitalism constitutes the United States as a capitalist state that is bound up with the authoritative rule of and for global capital. ${ }^{12}$ This leads to a second observation: because capitalism is global and deterritorialized, so, too, is global rule. ${ }^{113}$ Although the United States might play an important role in regulating the world economy, opening up new territories, and ensuring that rogue countries are disciplined, it works with other states and nonstate actors to maintain and expand global capitalism. ${ }^{114}$ Third, the regulation of the world economy is accomplished through a mixture of coercion and consent. The United States has demonstrated a willingness to use its military power to maintain global economic (and associated sociopolitical) stability. It also has worked hard to generate consent- that is, to get those who are structurally disadvantaged because of their position in the world political economy to accept the order of things. Accordingly, entering into the debate on U.S. empire through the lens of structural power leads one to a focus on the structural constitution of the conditions of possibility for the Bush administration's policies in relationship to the material, political, and ideological contradictions of capitalism. ${ }^{115}$

Can the social relations of constitution that generate empire be understood in the more diffuse terms of productive power? A most influential, recent, attempt is Hardt and Negri's definition of "empire," which has been the subject of much critical attention. Their argument is that transformative discursive and material processes have produced "empire": a "decentered and deterritorializing apparatus of rule that progressively incorporates the entire global realm within its open, expanding, frontiers." 116 What has produced this new form of global rule? Although they join others in identifying the expansion of global capital, they also locate an important role for the development of Western-backed institutions that maintain more consensual and participatory decision-making practices, new discourses such as human rights, equality, and democracy, and counterhegemonic struggles by labor and others that reflect the desire for "liberation" from the "modern machines of power." ${ }^{117}$ Empire, as they conceive it, is not a system in which tribute, power, and resources flow from the outlying regions to a great metropolitan center, but instead consists of more diffuse networks of hierarchy that generate privilege for some and pacify the multitudes.

111. See Gowan 2003; and Wallerstein 2003.

112. Aronowitz and Bratsis 2002.

113. See Robinson 2001; and Glassman 1999.

114. Panitch and Gindin 2003.

115. Anderson 2002. For an earlier analysis, see Augelli and Murphy 1988.

116. Hardt and Negri 2000, xi-xiii.

117. Ibid., 43. 
How does this deterritorialized empire constitute the United States? Broadly, social discourses might be viewed as productive of the specific subjectivity of the United States in relationship to imperial subjects. Some circles, for example, exhibit a growing romantic nostalgia for empire. ${ }^{118}$ It is not uncommon to hear the United States being urged to accept the responsibilities and burdens of empire in helping to bring progress to others. ${ }^{119}$ This role is to be performed not only by the United States. A multiplicity of actors and processes are partially responsible for attempting to bring progress, development, human rights, and the rule of law-in short, civilization - to the non-Western world. Along these lines, Judis observed that while there was the formal dismantling of the colonial empires that once played a civilizing mission that stabilized the international order, that role is now shouldered by international organizations. ${ }^{120} \mathrm{He}$ proceeded to recommend that the United States continue to use international organizations to perform this civilizing mission, anticipating that they will be better able to bring into being new kinds of actors in world politics. Productive power, in this way, works to produce a particular identity for the United States-a responsible and beneficent imperial actor in relation to others (imperial subjects, themselves irresponsible and in need of such help).

In general, any discussion of American empire should be attentive to all forms of power. Certainly there is compulsory power, which is the focus of much of the debate. Yet also present is institutional power and how the United States might indirectly control the behavior of others through global institutions. These first two approaches share, therefore, a concern with how the United States is able to sustain dominance in international affairs in ways that control, directly and indirectly, the foreign policies and even domestic political arrangements of other states. It is possible and desirable, though, to see the American empire as constituted by global social relations. Making this move requires a willingness to see the United States at the imperial center, structurally constituted and discursively produced through a complex of imperial relations that are not themselves fully under the control of the U.S. state as actor. To fully appreciate how power is embedded in empire, though, requires a willingness to see not only the different forms of power, but also how they combine in different ways to create structured and enduring hierarchies of control and advantage.

\section{Conclusion}

Power is a complex and contested concept, in large part because there are important but distinctive ways to understand how social relations shape the fates and

118. See Ferguson 2003; Mallaby 2002; and Kagan 2003.

119. USA Today, 6 May 2003, A15.

120. New Republic, 9 June 2003, 19-23. 
choices of actors. If international relations scholars have erred in their past attempts to understand power, it is by trying to identify and rely on a single conception. But no single concept can capture the forms of power in international politics. In order to better enable scholars to see the conceptual variety, we constructed a taxonomy that systematically identifies the different forms of power. We use that taxonomy to encourage scholars not to treat these conceptual forms as competing or vying for recognition as the important operation of power in a particular situation. Instead, we urge scholars to see how the multiple concepts capture the different and interrelated ways in which actors are enabled and constrained in determining their circumstances.

The inevitable question, then, is how exactly should we think about the relationship between these forms of power? During the past few years, there have been several important statements regarding how scholars should conceptualize the relationship between different substantive theories of international relations, such as neoliberalism and realism, and different social theories, such as constructivism and rationalism. ${ }^{121}$ Jupille, Caporaso, and Checkel suggest several possibilities: incommensurability; competitive testing; sequencing; incorporation (or subsumption); and some type of addition. ${ }^{122}$ With respect to analysis of power, we reject the first four in favor of the last.

One line of argument is that because these different conceptualizations of power derive, in important ways, from different social theoretic commitments, they are incommensurable. Because the theoretic foundations are in tension, the best that can be gotten among concepts of power is some form of conceptual pluralism. We certainly do not believe that a "master" theory of power is possible. But there is no social theoretic reason why scholars should not look for areas of connection. We also reject a gladiatorial competition between these conceptions; after all, they capture the different ways in which social relations shape and limit actors' ability to determine their fates. To permanently reject one in favor of another, therefore, would be to risk overlooking a fundamental dimension of power (and therefore return discussions of power to a state of conceptual myopia).

We also reject subsumption arguments, on the grounds that they presuppose that there is a foundational element of power that is generative of the other forms. We see ways in which compulsory power shapes productive power, and vice-versa; how institutional power shapes compulsory power, and vice-versa; how institutional power shapes structural power, and vice-versa, and on and on. So, there is no most basic form. On the same grounds, we reject the idea of sequencing because we see no reason to presume that one form of power necessarily and always precedes another. To the contrary, in most social contexts all are operating simultaneously, intersecting with and reflecting off of each other.

121. See, respectively, Baldwin 1993; Fearon and Wendt 2002; Katzenstein, Keohane, and Krasner 1999; and Tierney and Weaver 2003.

122. Jupille, Caporaso, and Checkel 2003. 
Because the taxonomy was designed to encourage scholars to see the different forms of power in international politics and the connections between them, we strongly encourage scholars to imagine how different forms interact to sharpen empirical analysis. Different forms of power have different domains of application to the extent that they illuminate different ways in which social relations affect and effect the ability of actors to control their fates. ${ }^{123}$ But, as we illustratively suggested in the discussions of global governance and American empire, these different conceptualizations are not only distinct, but also intertwined.

Although Carr is routinely considered to be the individual most responsible for establishing the focal conceptualization of power and associating that conceptualization with realism, in our view his work in fact suggests what we are advocating. ${ }^{124}$ As expected from someone deeply influenced by Mannheim and Marx, his Twenty Years' Crisis and his analysis of international order exhibit a far-reaching understanding of what power does and how power works. He certainly articulated various elements of compulsory power. His explicit discussion of power was largely limited to its multiple instruments (for him military force, economic wealth, and public opinion or propaganda) that could be used to overcome resistance from another "political society." Yet he also attended to features of institutional power as he saw how power works through international institutions, including international law, which, in turn, shape the policies of states and help to legitimate and sustain international orders. In Carr's view, international organizations, such as the League of Nations and emergent principles of international law, institutionalize the interests of the powerful and work against those of the weak. His critique of the League of Nations, therefore, included more than the standard (but false) criticism that its architects and advocates believed that somehow it would magically erase the causes of war; it also included the claim that these international institutions that embodied so-called universal principles, in fact, maintain the international status quo at the expense of some in the service of others. The hubris of idealists, Carr argued, is to believe that somehow these international institutions are antidotes to power and represent a positive-sum game. Indeed, for Carr, it was the very fact that they mask relations of power that transforms them into stealth weapons of domination.

As a student of Marx, Carr also saw power as structural-as including social processes that define state interests themselves. Drawing inspiration from Marxian theories of false consciousness, for example, he claimed that ideologies such as free trade are part of power politics precisely because they can lead indoctrinated states to consent to new forms of economic relations that insert them into new relations of dependence and exploitation. International orders are easier to sustain for the powerful if the dominated submit to their own domination, Carr acknowledged clearly and explicitly. Finally, as someone who was influenced by

123. For a related argument, see Baldwin 2002, 178.

124. Carr 1964. 
Mannheim, he was keenly aware of how broad discourses such as "progress," carried by intellectuals and established institutions, constitute what are acceptable practices and goals (always trying but never quite eradicating power) and shape broader categories of "civilized" and "uncivilized" states. Carr reminds us that power exists at the surface, and also well below; he shows that to understand power means to understand its various forms. As scholars of international relations continue to debate the nature, role, and explanatory significance of power, they should recognize the workings of multiple concepts and systematically employ them in their research. After all, that is the way Carr would have wanted it.

\section{References}

Abbott, Kenneth, and Duncan Snidal. 1998. Why States Act Through Formal International Organizations. Journal of Conflict Resolution 42 (1):3-32.

Anderson, Perry. 2002. Force and Consent. New Left Review 17 (September/October):5-30.

Arendt, Hannah. 1959. The Human Condition. New York: Anchor Books.

Aronowitz, Stanley, and Peter Bratsis. 2002. State Power, Global Power. In Paradigm Lost: State Theory Reconsidered, edited by Stanley Aronowitz and Peter Bratsis, xi-xxvii. Minneapolis: University of Minnesota Press.

Augelli, Enrico, and Craig Murphy. 1988. America's Quest for Supremacy and the Third World: A Gramscian Analysis. London: Pinter Publishers.

Ayoob, Mohamed. 1995. The Third World Security Predicament: State Making, Regional Conflict and the International System. Boulder, Colo.: Lynne Rienner.

Bacevich, Andrew. 2002. American Empire: The Realities and Consequences of U.S. Diplomacy. Cambridge, Mass.: Harvard University Press.

Bachrach, Peter, and Morton Baratz. 1962. Two Faces of Power. American Political Science Review 56 (4):947-52.

- 1963. Decisions and Nondecisions: An Analytic Framework. American Political Science Review 57 (3):632-42.

Baldwin, David. 1980. Interdependence and Power: A Conceptual Analysis. International Organization 34 (4):471-506.

1989. The Paradoxes of Power. New York: Basil Blackwell.

1993. Neorealism, Neoliberalism, and World Politics. In Neorealism and Neoliberalism: The Contemporary Debate, edited by David Baldwin, 3-25. New York: Columbia University Press.

- 2002. Power and International Relations. In The Handbook of International Relations, edited by Walter Carlsnaes, Thomas Risse, and Beth Simmons, 177-91. Thousand Oaks, Calif.: Sage Press.

Ball, Terrence. 1992. New Faces of Power. In Rethinking Power, edited by Thomas Wartenberg, 14-31. Albany: State University of New York Press.

Barnes, Barry. 1988. The Nature of Power. Cambridge: Polity Press.

Barnett, Michael. 1998. Dialogues in Arab Politics: Negotiations in Regional Order. New York: Columbia University Press.

Barnett, Michael, and Martha Finnemore. 2004. Rules for the World: International Organizations in Global Politics, Ithaca, N.Y.: Cornell University Press.

Benton, Ted. 1981. Objective Interests and the Sociology of Power. Sociology 15 (2):161-84.

Bhaskar, Roy. 1979. The Possibility of Naturalism: A Philosophical Critique of the Contemporary Human Sciences. Atlantic Highlands, N.J.: Humanities Press.

Blau, Peter. 1964. Exchange and Power in Social Life. New York: J. Wiley. 
Boli, John, and G. M. Thomas. 1999. INGOs and the Organization of World Culture. In Constructing World Culture: International Nongovernmental Organizations Since 1875, edited by J. Boli and G. M. Thomas, 13-49. Stanford, Calif.: Stanford University Press.

Bourdieu, Pierre. 2001. Masculine Domination. Stanford, Calif.: Stanford University Press.

Brass, Paul. 2000. Foucault Steals Political Science. Annual Review of Political Science 3:305-30.

Broad, Robin, ed. 2002. Global Backlash: Citizen Initiatives for a Just World Economy. Lanham, Md.: Rowman and Littlefield.

Butler, Judith. 1999. Gender Trouble: Feminism and the Subversion of Identity. New York: Routledge. Campbell, David. 1992. Writing Security: United States Foreign Policy and the Politics of Identity. Minneapolis: University of Minnesota Press.

Caporaso, James. 1978. Dependence, Dependency, and Power in the Global System: A Structural and Behavioral Analysis. International Organization 32 (1):13-43.

Carpenter, R. Charli. 2003. 'Women and Children First': Gender, Norms, and Humanitarian Evacuation in the Balkans, 1991-95. International Organization 57 (4):661-94.

Carr, E. H. 1964. The Twenty Year's Crisis, 1919-1939. New York: Harper and Row.

Checkel, Jeffrey. 2001. Why Comply? Social Learning and European Identity Change. International Organization 55 (3):553-88.

Clark, Anne Marie, E. Friedman, and Kathryn Hochstetler. 1998. The Sovereign Limits of Global Civil Society: A Comparison of NGO Participation in UN World Conferences on the Environment, Human Rights, and Women. World Politics 51 (1):1-35.

Claude, Inis. 1962. Power and International Relations. New York: Random House.

Commission on Global Governance. 1995. Our Global Neighborhood: The Report of the Commission on Global Governance. New York: Oxford University Press.

Cox, Robert. 1992. Multilateralism and World Order. Review of International Studies 18 (2):161-80.

Crawford, Neta. 2002. Argument and Change in World Politics: Ethics, Decolonization, and Humanitarian Intervention. New York: Cambridge University Press.

Dahl, Robert. 1957. The Concept of Power. Behavioral Science 2 (3):201-15.

— 2003. Can International Organizations Be Democratic: A Skeptic's View. In The Global Transformation Reader, edited by David Held and Anthony McGrew, 553-41. Boston: Polity Press.

Dahl, Robert, and Bruce Stinebrickner. 2003. Modern Political Analysis. 6th ed. Upper Saddle River, N.J.: Prentice Hall.

Digeser, Peter. 1992. The Fourth Face of Power. Journal of Politics 54 (4):977-1007.

Doyle, Michael. 1986. Empires. Ithaca, N.Y.: Cornell University Press.

Doty, Roxanne. 1996. Imperial Encounters: The Politics of Representation in North-South Relations. Minneapolis: University of Minnesota Press.

Emerson, Richard. 1962. Power-Dependence Relations. American Sociological Review 27 (1):31-41.

Fairclough, Norman. 1992. Discourse and Social Change. Cambridge, Mass.: Polity Press.

Fearon, James, and Alexander Wendt. 2002. Rationalism vs. Constructivism: A Skeptical View. In Handbook of International Relations, edited by Walter Carlnaes, Thomas Risse, and Beth Simmons, 52-72. Thousand Oaks, Calif.: Sage Press.

Ferguson, James. 1994. The Anti-Politics Machine: "Development," Depoliticization, and Bureaucratic Power in Lesotho. Minneapolis: University of Minnesota Press.

Ferguson, Niall. 2003. Empire: The Rise and Demise of the British World Order and the Lessons for Global Power. New York: Basic Books.

Finnemore, Martha. 1996. Norms, Culture, and World Politics: Insights from Sociology's Institutionalism. International Organization 50 (2):325-47.

2003. The Purpose of Intervention: Changing Beliefs About the Use of Force. Ithaca, N.Y.: Cornell University Press.

Foucault, Michel. 1971. The Order of Things: An Archeology of the Human Sciences. New York: Pantheon. 
1983. Afterword: The Subject and Power. In Michel Foucault: Beyond Structuralism and Hermeneutics, 2d ed, edited by Hubert Dreyfus and Paul Rabinow, 208-26. Chicago: University of Chicago Press.

1984. The Juridical Apparatus. In Legitimacy and the State, edited by William Connolly, 201-22.

New York: New York University Press.

1995. Discipline and Punish: The Birth of the Prison. New York: Vintage.

Gallie, W. B. 1956. Essentially Contested Concepts. Proceedings of the Aristotelian Society 56:167-98.

Garrett, Geoffrey, and George Tsebelis. 1999. Why Resist the Temptation to Apply Power Indices to the European Union? Journal of Theoretical Politics 11 (3):291-308.

Giddens, Anthony. 1979. Central Problems in Social Theory: Action, Structure, and Contradiction in Social Analysis. Berkeley: University of California Press.

1984. The Constitution of Society: Outline of the Theory of Structuration. Berkeley: University of California Press.

Gill, Stephen, and David Law. 1989. Global Hegemony and the Structural Power of Capital. International Studies Quarterly 33 (4):475-99.

Gilpin, Robert. 2002. A Realist Perspective on International Governance. In Governing Globalization: Power, Authority, and Governance, edited by David Held and Anthony McGrew, 237-48. Cambridge: Polity Press.

Glassman, Jim. 1999. State Power Beyond the 'Territorial Trap': The Internationalization of the State. Political Geography 18 (6):669-96.

Goldstein, Judith. 1989. The Impact of Ideas on Trade Policy: The Origins of U.S. Agricultural and Manufacturing Policies. International Organization 43 (1):31-71.

Gordeneker, Leon, and Thomas Weiss. 1996. Pluralizing Global Governance: Analytical Approaches and Dimensions. In NGOs, the UN, and Global Governance, edited by Leon Gordeneker and Thomas Weiss, 17-47. Boulder, Colo.: Lynne Reinner.

Gowan, Peter. 2003. U.S. Hegemony Today. Monthly Review 55 (3):30-50.

Gruber, Lloyd. 2000. Ruling the World: Power, Politics, and the Rise of Supranational Institutions. Princeton, N.J.: Princeton University Press.

Guzzini, Stefano. 1993. Structural Power: The Limits of Neorealist Power Analysis. International Organization 47 (3):443-78.

-1998. Realism in International Relations and International Political Economy. New York: Routledge.

- 2000. The Use and Misuse of Power Analysis in International Theory. In Global Political Economy: Contemporary Theories, edited by Ronon Palan, 53-66. New York: Routledge.

- 2002. 'Power' in International Relations: Concept Formation Between Conceptual Analysis and Conceptual History. Paper presented at the 43d Annual Convention of the International Studies Association, March, New Orleans, La.

Habermas, Jurgen. 1986. The Theory of Communicative Action, Volume 1: Reason and the Rationalization of Society. Cambridge, Mass.: Polity Press.

Hardt, Michael, and Antonio Negri. 2000. Empire. Cambridge, Mass.: Harvard University Press.

Harrell-Bond, Barbara. 2002. Can Humanitarian Work with Refugees Be Humane? Human Rights Quarterly 24 (1):51-85.

Hay, Colin. 1997. Divided by a Common Language: Political Theory and the Concept of Power. Politics 17 (1):45-52.

Hayward, Clarissa Rile. 2000. De-Facing Power. New York: Cambridge University Press.

Hempel, Carl. 1952. Fundamentals of Concept Formation in Empirical Science. Chicago: University of Chicago Press.

1965. Fundamentals of Taxonomy. In Aspects of Scientific Explanation, edited by Carl Hempel, 137-54. New York: Free Press.

Hirschman, Albert. 1945. National Power and the Structure of Foreign Trade. Berkeley: University of California Press. 
Hurrell, Andrew. 2005. Power, Institutions and the Production of Inequality. In Power and Global Governance, edited by Michael Barnett and Raymond Duvall, 33-58. New York: Cambridge University Press.

Hurrell, Andrew, and Ngaire Woods. 1993. Globalization and Inequality. Millennium 24 (3):447-70.

Ikenberry, G. John. 2001. After Victory: Institutions, Strategic Restraint, and the Rebuilding of Order. Princeton, N.J.: Princeton University Press.

- 2001. American Power and the Empire of Capitalist Democracy. Review of International Studies 27 (5):191-212.

- 2002. America's Imperial Ambition. Foreign Affairs 81 (September/October):44-60.

Ikenberry, G. John, and Charles A. Kupchan. 1990. Socialization and Hegemonic Power. International Organization 44 (3):283-315.

Inayatullah, Naeem, and David Blaney. 2003. International Relations and the Problem of Difference. New York: Routledge.

Isaac, Jeffrey. 1987. Power and Marxist Theory. Ithaca, N.Y.: Cornell University Press.

Joachim, Jutta. 2003. Framing Issues and Seizing Opportunities: The UN, NGOs, and Women's Rights. International Studies Quarterly 47 (2):247-74.

Johnstone, Ian. 2003. Security Council Deliberations: The Power of the Better Argument. European Journal of International Law 14 (3):437-80.

Jupille, Joseph, James Caporaso, and Jeffrey Checkel. 2003. Integrating Institutions: Rationalism, Constructivism, and the Study of the European Union. Comparative Political Studies 36 (1-2):7-40.

Kagan, Robert. 2003. Of Paradise and Power: America and Europe in the New World Order. New York: Knopf.

Kapstein, Ethan. 1999. Sharing the Wealth: Workers and the World Economy. New York: Norton.

Katzenstein, Peter, ed. 1996. The Culture of National Security: Norms and Identity in World Politics. New York: Columbia University Press.

Katzenstein, Peter, Robert Keohane, and Steven Krasner. 1999. International Organization at Fifty. In Exploration and Contestation in the Study of World Politics, edited by Peter Katzenstein, Robert Keohane, and Steven Krasner, 5-45. Cambridge, Mass.: MIT Press.

Keck, Margaret, and Kathryn Sikkink. 1998. Activists Beyond Borders: Advocacy Networks in International Politics. Ithaca, N.Y.: Cornell University Press.

Kendall, Gavin, and Gary Wickham. 1999. Using Foucault's Methods. Thousand Oaks, Calif.: Sage Publications.

Keohane, Robert. 1984. After Hegemony: Cooperation and Discord in the World Political Economy. Princeton, N.J.: Princeton University Press.

— 2001. Governance in a Partially Globalized World. American Political Science Review 95 (1):1-14.

2003. The Concept of Accountability in World Politics and the Use of Force. Michigan Journal of International Law 24(4): 1-21.

Keohane, Robert, and Lisa Martin. 1995. The Promise of Institutionalist Theory. International Security 20 (1):39-51.

Keohane, Robert, and Joseph Nye. 1977. Power and Interdependence. Boston: Little, Brown.

- 2003. Redefining Accountability for Global Governance. In Governance in a Global Economy: Political Authority in Transition, edited by Miles Kahler and David Lake, 361-92. Princeton, N.J.: Princeton University Press.

Kinsella, Helen. 2003. The Image Before the Weapon: A Genealogy of the 'Civilian' in International Law and Politics. Ph.D. diss., University of Minnesota, Minneapolis.

Knight, Jack. 1992. Institutions and Social Conflict. New York: Cambridge University Press.

Knorr, Klaus. 1973. Power and Wealth: The Political Economy of International Power. New York: Basic Books.

Kondo, Dorinne. 1990. Crafting Selves: Power, Gender, and Discourses of Identity in a Japanese Workplace. Chicago: University of Chicago Press.

Krasner, Stephen. 1983. International Regimes. Ithaca, N.Y.: Cornell University Press. 
1985. Structural Conflict: The Third World Against Global Liberalism. Berkeley: University of California Press.

1991. Global Communications and National Power: Life on the Pareto Frontier. World Politics 43 (3):336-66.

Kupchan, Charles. 2002. The End of the American Era: U.S. Foreign Policy and the Geopolitics of the Twenty-First Century. New York: Knopf.

Laswell, Harold, and Abraham Kaplan. 1980. Power and Society: A Framework for Political Inquiry. New Haven, Conn.: Yale University Press.

Latham, Robert. 1999. Politics in a Floating World: Toward a Critique of Global Governance. In Approaches to Global Governance Theory, edited by Martin Hewson and Timothy J. Sinclair, 23-53. Albany: State University of New York Press.

Litwak, Robert. 2002. The New Calculus of Pre-emption. Survival 44 (4):53-80.

Loescher, Gil. 2001. UNHCR and World Politics. New York: Oxford University Press.

Lukes, Steven. 1975. Power: A Radical View. Houndmills, England: MacMillan Education.

Macdonell, Diane. 1986. Theories of Discourse: An Introduction. New York: Blackwell.

Mallaby, Sebastian. 2002. The Reluctant Imperialist: Terrorism, Failed States, and the Case for American Empire. Foreign Affairs 81 (2):2-7.

Mansbach, Richard W., and John A. Vasquez. 1981. In Search of Theory: A New Paradigm for Global Politics. New York: Columbia University Press.

Mansfield, Edward. 1993. Concentration, Polarity, and the Distribution of Power. International Studies Quarterly 37 (1):105-28.

Maoz, Zeev. 1989. Paradoxes of War: On the Art of National Self-Entrapment. Boston: Unwin Hyman.

Mearsheimer, John. 2001. The Tragedy of Great Power Politics. New York: Norton.

Mehta, Pratap Bhanu. 2003. Empire and Moral Identity. Ethics and International Affairs 17 (2):49-62.

Mommsen, Wolfgang. 1986. The End of Empire and the Continuity of Imperialism. In Imperialism and After: Continuities and Discontinuities, edited by Wolfgang Mommsen and Jürgen Osterhammel, 333-58. Boston: Allen \& Unwin.

Moravcsik, Andrew. 1997. Taking Preferences Seriously: A Liberal Theory of International Politics. International Organization 51 (4):513-54.

Morgenthau, Hans. 1967. Politics Among Nations: The Struggle for Power and Peace. 4th ed. New York: Knopf.

Murphy, Craig. 1984. Emergence of the NIEO Ideology. Boulder, Colo.: Westview Press.

- 1994. International Organizations and Industrial Change. New York: Oxford University Press.

Neumann, Iver. 1999. Uses of the Other: The East in European Identity Formation. Minneapolis: University of Minnesota Press.

Neumann, Iver, and Jennifer Welsh. 1991. The Other in European Self-Definition: An Addendum to the Literature on International Society. Review of International Studies 17 (4):327-48.

Nye, Joseph. 1990. Soft Power. Foreign Policy 80:153-71.

- 2002. The Paradox of American Power: Why the World's Only Superpower Can't Go it Alone. New York: Oxford University Press.

2003. U.S. Power and Strategy After Iraq. Foreign Affairs 82 (4):60-73.

Oppenheim, Felix. 1981. Political Concepts: A Reconstruction. Chicago: University of Chicago Press.

Panitch, Leo, and Sam Gindin. 2003. Global Capitalism and American Empire. In The New Imperial Challenge: Socialist Register 2004, edited by Leo Panitch and Colin Leys, 3-27. New York: Monthly Review Press.

Pierson, Paul. 2000. The Limits of Design: Explaining Institutional Origins and Change. Governance 13 (4):475-99.

Pollack, Mark. 2003. Engines of European Integration: Delegation, Agency, and Agenda Setting in the $E U$. New York: Oxford University Press.

Prakash, Aseem, and Jeffrey Hart. 1999. Globalization and Governance: An Introduction. In Globalization and Governance, edited by Aseem Prakash and Jeffrey Hart, 1-24. New York: Routledge Press. 
Price, Richard. 1998. Reversing the Gun Sights: Transnational Civil Society Targets Land Mines. International Organization 52 (3):613-44.

Ray, James Lee, and J. David Singer. 1973. Measuring the Concentration of Power in the International System. Sociological Methods \& Research 1 (4):403-37.

Risse, Thomas. 2001. Let's Argue: Communicative Action in International Relations. International Organization 54 (1):1-40.

Risse, Thomas, Steve Ropp, and Kathryn Sikkink., eds. 1999. The Power of Human Rights. New York: Cambridge University Press.

Robinson, William. 2001. Social Theory and Globalization: The Rise of a Transnational State. Theory and Society 30 (2):57-200.

Rosen, Stephen. 2003. An Empire, If You Can Keep It. The National Interest Spring: 51-60.

Ruggie, John. 2001. Global Governance.net: The Global Compact as Learning Network. Global Governance 7 (4):371-78.

. The Theory and Practice of Learning Networks: Corporate Social Responsibility and the Global Compact. Journal of Corporate Citizenship 5:27-35.

Rupert, Mark. 2000. Ideologies of Globalization: Contending Visions of a New World Order. New York: Routledge.

Rupert, Mark, and Hazel Smith, eds. 2002. Historical Materialism and Globalization. New York: Routledge.

Russell, Bertrand. 1986. The Forms of Power. In Power, edited by Steven Lukes, 19-27. New York: New York University Press.

Scott, John. 2001. Power. New York: Polity.

Sen, Amartya. 1999. Development as Freedom. New York: Knopf.

Shaffer, Greg. 2005. Power, Global Governance, and the WTO: The Need for a Comparative Institutional Approach. In Power in Global Governance, edited by Michael Barnett and Raymond Duvall, 130-60. New York: Cambridge University Press.

Shaw, Martin. 2002. Post-Imperial and Quasi-Imperial: State and Empire in the Global Era. Millennium 31 (2):327-36.

Slaughter, Anne-Marie. 1995. International Law in a World of Liberal States. European Journal of International Law 6 (4):503-38.

Stiglitz, Joseph. 2002. Globalization and its Discontents. New York: Norton.

Stoll, Richard, and Michael Ward, eds. 1989. Power in World Politics. Boulder, Colo.: Lynne Rienner.

Strange, Susan. 1989. Toward a Theory of Transnational Empire. In Global Changes and Theoretical Challenges, edited by Ernst-Otto Czempiel and James N. Rosenau, 161-76. Lexington, Mass.: Lexington Books.

Tierney, Michael, and Catherine Weaver. 2003. Principles or Principals? Beyond Theoretical Divides in the Study of International Organizations. Unpublished manuscript, University of Kansas, Lawrence.

Vasquez, John. 1998. The Power of Power Politics: From Classical Realism to Neotraditionalism. New York: Cambridge University Press.

Wallerstein, Immanuel. 1996. The Interstate Structure of the Modern World-System. In International Theory: Positivism and Beyond, edited by Steve Smith, Ken Booth, and Marysia Zalewski, 171-85. New York: Cambridge University Press.

. 1998. The New World Disorder: If the States Collapse, Can the Nations Be United? In Between Sovereignty and Global Governance: The United Nations, the State and Civil Society, edited by Albert Paolini, Anthony Jarvis, and Christian Reus-Smit, 171-85. New York: St. Martin's Press.

- 2003. The Decline of American Power: The U.S. in a Chaotic World. New York: New Press.

Waltz, Kenneth N. 1999. Globalization and Governance. PS Online (December). Available at $\langle\mathrm{http}: / /$ www.apsanet.org/PS/dec99/waltz.cfm〉. Accessed 19 April 2004.

Wartenberg, Thomas. 1992. Situated Social Power. In Rethinking Power, edited by Thomas Wartenberg, 79-101. Albany: State University of New York Press.

Weber, Max. 1947. The Theory of Social and Economic Organization. Translated by A. M. Henderson and Talcott Parsons. New York: Free Press. 
Wellens, Karel. 2002. Remedies Against International Organisations. New York: Cambridge University Press.

Wendt, Alexander. 1998. On Constitution and Causation in International Relations. Review of International Studies 24 (special issue):101-18. 1999. Social Theory of International Politics. New York: Cambridge University Press.

Wendt, Alexander, and Raymond Duvall. 1989. Institutions and International Order. In Global Changes and Theoretical Challenges, edited by Ernst Otto Czempiel and James N. Rosenau, 51-73. Lexington, Mass.: Lexington Books.

Williams, Michael. 1996. Hobbes and International Relations: A Reconsideration. International Organization 50 (2):213-36.

Wrong, Dennis. 1988. Power: Its Forms, Bases, and Uses. Chicago: University of Chicago Press.

Young, Oran. 1994. International Governance: Protecting the Environment in a Stateless Society. Ithaca, N.Y.: Cornell University Press. 